\title{
An abundant hydrophobin (ABH1) forms hydrophobic rodlet layers in Agaricus bisporus fruiting bodies
}

\author{
Luis G. Lugones, Jaap S. Bosscher, Karin Scholtmeyer, \\ Onno M. H. de Vries and Joseph G. H. Wessels
}

Department of Plant Biology, Groningen Biomolecular Sciences and Biotechnology Institute (GBB), University of Groningen, Kerklaan 30, 9751 NN Haren, The Netherlands

\author{
Author for correspondence: Iuis G. Lugones. Tel: +31 50 3632322. Fax: +31503632272. \\ e-mail: L.G.Lugones@biol.rug.nl
}

\begin{abstract}
The SDS-insoluble protein fraction of Agaricus bisporus fruiting bodies was solubilized with trifluoroacetic acid. On SDS-PAGE this fraction was found to contain one abundant protein with an apparent $M_{r}$ of $16 \mathrm{kDa}$. The $\mathrm{N}$-terminal amino acid sequence of this protein was determined and RT-PCR used to isolate a cDNA clone which upon sequencing identified the protein as a typical class I hydrophobin (ABH1). The gene (ABH1) was isolated and sequenced, and a second hydrophobin gene (ABH2) was found about $2.5 \mathrm{kbp}$ downstream of $A B H 1$. Purified ABH1 self-assembled at hydrophobic-hydrophilic interfaces, producing the typical rodlet layer known from other hydrophobins. Similar rodlets were observed on the surface of the fruiting body, while immunological localization showed the hydrophobin to be particularly abundant at the outer surface of fruiting bodies, in the veil and in the core tissue of the stipe. Transcripts of $A B H 1$ were found only in fruiting-body hyphae. The ABH1 hydrophobin is probably solely responsible for the hydrophobicity of the fruiting-body surface but may also line air channels within fruiting bodies.
\end{abstract}

Keywords: Agaricus bisporus, hydrophobin, wall protein, mushroom, fruiting body

\section{INTRODUCTION}

Hydrophobins are small, moderately hydrophobic proteins secreted by fungi and characterized by a conserved spacing of eight cysteine residues and a typical hydropathy pattern (Wessels, 1994). Although sequences putatively encoding such proteins have been found in many species, only a few hydrophobins have been characterized. Those that have been studied exhibit interfacial self-assembly, that is, they form amphipathic protein films when confronted with a hydrophobichydrophilic interface, such as between air and water. On the basis of the solubility of these protein films two hydrophobin classes were distinguished (Wessels, 1994). Class I hydrophobins, exemplified by the SC3 hydro-

Abbreviations: TFA, trifluoroacetic acid; BCIP, 5-bromo-4-chloro-3indolyl phosphate $p$-toluidine salt; NBT, nitro blue tetrazolium chloride; RT, reverse transcriptase.

The GenBank accession numbers for the sequences reported in this paper are $\mathrm{X} 92861$ and $\mathrm{X} 92860$ for $A B H 1$ and $A B H 2$, respectively. phobin of Schizopbyllum commune (Schuren \& Wessels, 1990), form very stable SDS-insoluble protein films (Wessels et al., 1991; Wösten et al., 1993, 1994a). Class II hydrophobins, exemplified by cerato-ulmin from Ophiostoma ulmi (Bowden et al., 1994), form unstable SDSsoluble films (Richards, 1993).

The SC3 hydrophobin of S. commune is known to assemble at the surface of aerial hyphae and to cover these with a hydrophobic rodlet layer (Wessels et al., 1991; Wösten et al., 1993, 1994b). Genetic experiments have indicated that the hydrophobic rodlet layers on conidiospores of Aspergillus nidulans (Stringer et al., 1991) and Neurospora crassa (Bell Pedersen et al., 1992; Lauter et al., 1992) also consist of hydrophobin assemblages. The occurrence of a class I hydrophobin-like protein secreted by the substrate mycelium of the edible mushroom Agaricus bisporus has been reported by de Vries et al. (1993). Here we report the isolation of a class I hydrophobin from the fruiting bodies of this organism. The gene ( $A B H 1)$ encoding this protein and a closely linked putative hydrophobin gene $(A B H 2)$ were cloned. $\mathrm{ABH} 1$ was found to self-assemble at hydrophilic-hydrophobic interfaces, and to form a hydro- 
phobic rodlet layer at the surface of the fruiting body and probably at surfaces of air spaces within the plectenchyma.

\section{METHODS}

Organism and culture conditions. Young Agaricus bisporus (cultivar U1 and a brown variant C9) fruiting body primordia measuring $10 \mathrm{~mm}$ in diameter (pinheads) and $25 \mathrm{~mm}$ (buttons) were kindly provided by $\mathrm{Mr}$ B. Boer (Mushroom Farm Agarica BV, Hoogeveen, The Netherlands). After picking they were immediately processed or frozen in liquid nitrogen and stored at $-81^{\circ} \mathrm{C}$. Substrate mycelium was obtained by inoculating $25 \mathrm{ml}$ Schizopbyllum commune minimal medium (Dons et al., 1979) contained in plastic $9 \mathrm{~cm}$ Petri dishes with homogenized mycelium of $A$. bisporus cultivar $\mathrm{U} 1$ and growing at $24^{\circ} \mathrm{C}$ for $10 \mathrm{~d}$.

Isolation and purification of ABH1. Frozen pinheads of $A$. bisporus were passed through an X-press. The fragmented material was quickly thawed and suspended in 10 vols hot washing buffer $(1 \%, \mathrm{w} / \mathrm{v}, \mathrm{SDS}, 0.1 \mathrm{M}$ sodium phosphate buffer pH 7.0 at $100^{\circ} \mathrm{C}$ ) and the suspension kept at $100^{\circ} \mathrm{C}$ for $10 \mathrm{~min}$. After centrifugation the residue was washed six times with 8 vols water and freeze-dried. The dried residue was subsequently extracted with concentrated trifluoroacetic acid (TFA, $0.1 \mathrm{ml}$ $\mathrm{mg}^{-1}$ ) at $0{ }^{\circ} \mathrm{C}$. After removing solids by centrifugation, the TFA was removed from the supernatant with a stream of nitrogen and $60 \%(\mathrm{v} / \mathrm{v})$ ethanol $(0.2 \mathrm{ml}$ per $\mathrm{mg}$ dried SDS-insoluble residue) was added to the residue. After standing overnight at room temperature, non-dissolved material was removed by centrifugation and the supernatant was freeze-dried. Before use, the purified $\mathrm{ABH} 1$ was treated with TFA as above and dissolved in water.

Gel electrophoresis of proteins. For SDS-PAGE, the TFAtreated material was taken up in sample buffer $(50 \mathrm{mM}$ Tris $/ \mathrm{HCl}$ $\mathrm{pH} \mathrm{6.8,} \mathrm{2 \%} \mathrm{SDS,} 10 \%, \mathrm{v} / \mathrm{v}$, glycerol, $5 \%, \mathrm{v} / \mathrm{v}, 2-$ mercaptoethanol, $0.002 \%$ bromophenol blue) and the $\mathrm{pH}$ adjusted with $5 \%(\mathrm{v} / \mathrm{v})$ ammonia to $6 \cdot 8$, if required. Electrophoresis was done in $12.5 \%(\mathrm{w} / \mathrm{v})$ polyacrylamide gels according to Laemmli (1970). Gels were stained with either Coomassie Blue (Neuhof et al., 1988) or silver (Merril et al., 1981). For sequencing, immuno-detection and carbohydrate staining, proteins were transferred to PVDF membranes (Immobilon-P, Millipore) by semi-dry blotting (Multiphor II Electrophoresis System, Pharmacia) at $0.8 \mathrm{~mA} \mathrm{~cm}^{-2}$ for $2 \mathrm{~h}$ with electrophoresis buffer containing $20 \%$ ethanol.

For sequencing, blots were stained with Coomassie Brilliant Blue R250 in 10\% (v/v) acetic acid, 30\% (v/v) methanol, and de-stained in the same solvent. Amino-terminal sequencing was carried out on a cut-out band from the gel blot with a pulse liquid sequenator on-line connected to a phenylthiohydantoin analyser (Applied Biosystems).

For immuno-staining, blots were incubated in blocking solution [6.5 mM Na $\mathrm{HPO}_{4}, 1.5 \mathrm{mM} \quad \mathrm{KH}_{2} \mathrm{PO}_{4}, 2.7 \mathrm{mM} \mathrm{KCl}$ and $150 \mathrm{mM} \mathrm{NaCl}, \mathrm{pH} 7 \cdot 2(1 \times \mathrm{PBS}) ; 0.1 \%$ Triton X-100; $5 \%$ (w/v) skim milk powder] for $2 \mathrm{~h}$ followed by incubation with ABH1 antiserum (1/2000 in the same buffer) for $1 \mathrm{~h}$ and then $1 \mathrm{~h}$ with goat-anti-rabbit antibodies conjugated to alkaline phosphatase (Boehringer 605230, 1:6000 in the same buffer). After each incubation, the blots were washed five times with $1 \times$ PBS, $0 \cdot 1 \%$ Triton $\mathrm{X}-100$ for $5 \mathrm{~min}$. Blots were then incubated with substrate solution containing $0.4 \mathrm{mM}$ NBT (nitro blue tetrazolium chloride), 0.4 mM BCIP (5-bromo-4chloro-3-indolyl-phosphate $p$-toluidine salt), $100 \mathrm{mM} \mathrm{NaCl}$, $5 \mathrm{mM} \mathrm{MgCl}_{2}$ and $100 \mathrm{mM}$ Tris $\mathrm{pH} 9 \cdot 5$. Proteins in blots were made visible by the silver staining method for blots described in the Phast System manual (Pharmacia). For detection of carbohydrates, blots were incubated for $1 \mathrm{~h}$ at room temperature in $0.5 \%(\mathrm{w} / \mathrm{v})$ periodic acid, washed once for $5 \mathrm{~min}$ in $5 \%(\mathrm{v} / \mathrm{v})$ acetic acid, and stained with Schiff reagent (Sigma).

Preparation of antiserum against ABH1. After electrophoresis and blotting to PVDF membrane, ABH1 was eluted with TFA from a strip of the membrane. After removing TFA the protein was used for immunization of rabbits. The recovered antiserum reacted specifically with $\mathrm{ABH} 1$ and not with other $A$. bisporus proteins, nor with the SC3 or SC4 hydrophobins of $S$. commune. Pre-immune serum was unreactive in all cases. For immunolocalization studies, the antiserum (diluted 1/100) was purified as described by Wösten et al. (1994b) by incubating three times for $60 \mathrm{~min}$ with a mixture of cell walls from submerged-grown mycelium of $A$. bisporus $\left(1 \mathrm{mg} \mathrm{ml}^{-1}\right)$ and $S$. commune $\left(1 \mathrm{mg} \mathrm{ml}^{-1}\right)$ prepared according to Sietsma et al. (1977).

RNA isolation. Frozen fruiting bodies (pinheads) were ground to a powder under liquid nitrogen in a mortar and RNA was extracted by the hot phenol procedure (Wessels et al., 1987).

CDNA clone isolation. First strand synthesis was done in a $50 \mu \mathrm{l}$ reaction mixture containing $2 \mu \mathrm{l}$ total-RNA solution, $1 \mathrm{U}$ reverse transcriptase (Superscript-RT, Gibco BRL), $125 \mu \mathrm{M}$ of each of the four nucleotides, $290 \mathrm{nM}$ oligo-dT (26-mer), $2 \mathrm{mM}$ DTT, and $1 \mu \mathrm{l}$ RNA-guard (Pharmacia) in $1 \times \mathrm{RT}$-buffer (supplied with the enzyme). Incubation was for $1 \mathrm{~h}$ at $37^{\circ} \mathrm{C}$. After 2 min denaturation at $94^{\circ} \mathrm{C}$, an aliquot was taken for PCR $(2 \mu \mathrm{l}$ per $100 \mu \mathrm{l}$ reaction mixture). Reaction mixtures for PCR contained $0 \cdot 1 \mathrm{U}$ Supertaq-polymerase (H'T Biotechnology) or $1 \mathrm{U}$ Vent-polymerase (New England Biolabs) and buffer supplied by the manufacturers. PCR was performed in $100 \mu \mathrm{l}$ $1 \times$ buffer with $125 \mu \mathrm{M}$ of each nucleotide, $300 \mathrm{nM}$ oligo-dT (26-mer with an additional $X h o I$ restriction site) as reverse primer and $1 \mu \mathrm{M}$ degenerate or $0 \cdot 1 \mu \mathrm{M}$ non-degenerate forward primer. The forward primers contained a SacI site for easy cloning purposes. A moderately stringent annealing profile $\left(1 \mathrm{~min}, 50^{\circ} \mathrm{C}\right)$ was used. Denaturation was at $94^{\circ} \mathrm{C}$ for $1 \mathrm{~min}$ and elongation was at $72^{\circ} \mathrm{C}$ for $1.5 \mathrm{~min}$.

Gene cloning and DNA sequencing. A partial Sau3A library, in Lambda FIX II, of $A$. bisporus strain Horst ${ }^{\mathrm{R}} \mathrm{U} 3$ (Harmsen $e$ t al., 1992) was screened using the $A B H 1 \mathrm{cDNA}$ fragment as probe. Hybridizations were done as described by Schuren et al. (1993). Clones of the $A B H 1 \mathrm{cDNA}$ and genomic subclones were constructed in pUC vectors or derivatives. Nucleotide sequences of the gene and the cDNA were determined by independently sequencing from both strands. Sequencing was performed with the T7 DNA polymerase kit from Pharmacia using the dideoxy chain-termination method (Sanger et al., 1977).

Interfacial self-assembly. For assembly of $\mathrm{ABH} 1$ on the hydrophobic surface of polytetrafluoroethylene (PTFETeflon), Teflon discs of $0.5 \mathrm{~cm}$ diameter, $0.5 \mathrm{~mm}$ thick, were first cleaned in chromic acid and then incubated with an aqueous ABH1 solution for $1 \mathrm{~h}$. The discs were subsequently extracted with $1 \%(\mathrm{w} / \mathrm{v})$ SDS at $100{ }^{\circ} \mathrm{C}$, washed in distilled water, dried in air, and the hydrophobicity of the surface was measured by determining water contact angles (van der Mei et al., 1991). Immuno-detection of the hydrophobin on the discs was basically done as indicated for blotted proteins but with the second antibody conjugated to horseradish peroxidase (BRL, 9814SA, $1: 3000)$. Discs were then placed in the wells of a micro-titre plate and $200 \mu \mathrm{l}$ substrate (o-phenylenediamine dihydrochloride, $0.2 \mathrm{mg} \mathrm{ml}^{-1}, 50 \mathrm{mM}$ phosphate/citrate buffer $\mathrm{pH} \mathrm{5.0)}$ was added per well. The reaction was stopped by adding $50 \mu \mathrm{l} 3 \mathrm{M} \mathrm{HCl}$ and $A_{490}$ read with an ELISA microplate reader (Bio-Rad, model 
450). For assembly of $\mathrm{ABH} 1$ on a hydrophilic surface an aqueous solution of the hydrophobin $\left(0.2 \mathrm{mg} \mathrm{ml}^{-1}\right)$ was allowed to ascend in a filter paper strip (Schleicher \& Schuell no. 0860, $20 \times 0.6 \mathrm{~cm}$ ) in open air. After $18 \mathrm{~h}$, allowing for evaporation of about $2 \mathrm{ml}$ water, the paper strip was dried and extracted with $1 \%$ SDS at $100^{\circ} \mathrm{C}$ for $10 \mathrm{~min}$, washed with water and dried for measurement of hydrophobicity. Surface hydrophobicity was estimated by measuring water contact angles.

Immuno-histochemistry. Fruiting body sections $(70 \mu \mathrm{m})$ were cut with a microslicer (Slicetome MW-1000, Meiwa Shojo) under $1 \%(\mathrm{w} / \mathrm{v})$ PVP (polyvinylpyrrolidone) and placed on glass microscope slides coated with chrome-alum-gelatin. The sections were firmly attached to the slides by exposure to formaldehyde vapours for $30 \mathrm{~min}$ and allowed to dry. Sections were placed in blocking solution $(1 \times \mathrm{PBS}, 0.1 \%$ Triton $\mathrm{X}-100$, $1 \%$ BSA, $1 \%$ PVP, $0.5 \%$ normal goat serum, $0.02 \% \mathrm{NaN}_{3}$ ) for $15 \mathrm{~h}$ and then for $15 \mathrm{~h}$ in a $1 / 1200$ dilution of purified $\mathrm{ABH} 1$ antiserum in blocking solution. After three washes in $1 \times \mathrm{PBS}$, $0 \cdot 1 \%$ Triton $\mathrm{X}-100$, they were incubated for $5 \mathrm{~h}$ in a $1 / 6000$ dilution of goat-anti-rabbit antibodies conjugated to alkaline phosphatase in blocking solution. After six washes of $20 \mathrm{~min}$ each in $1 \times$ PBS, $0.1 \%$ Triton X-100, NBT/BCIP was used to detect the enzyme as described for immuno-staining of blots. To differentiate the stain from dark pigments arising from oxidation of phenolic compounds within fruiting bodies, stained sections were treated with a $0.4 \%$ solution of sodium hypochlorite for 5 min.

Electron microscopy. For visualization of rodlets on the hydrophobic side of assembled ABH1, $5 \mu$ l of a solution of $\mathrm{ABH} 1$ (approx. $5 \mu \mathrm{g} \mathrm{ml}^{-1}$ ) was allowed to dry on Formvarcoated nickel grids. Surface shadowing with $\mathrm{Pt} / \mathrm{C}$ was done at an angle of $45^{\circ} \mathrm{C}$. For freeze-fracture, tissue pieces of $2 \mathrm{~mm}^{3}$ were fixed in $4 \%(\mathrm{v} / \mathrm{v})$ formaldehyde in vacuo, equilibrated with $50 \%$ aqueous glycerol, and then frozen in liquid-nitrogencooled propane. Freeze-fracturing was done in a freeze-etch unit (Balzers). Replicas were made using $\mathrm{Pt} / \mathrm{C}$ and cleaned in $\mathrm{K}_{2} \mathrm{Cr}_{2} \mathrm{O}_{7}$-saturated $\mathrm{H}_{2} \mathrm{SO}_{4}$ for $90 \mathrm{~min}$. Replicas were also made directly from the fruiting body surface. Replicas and shadowed material were examined in a Philips CM 10 electron microscope. Photographs were made on FGP Kodak film.

\section{RESULTS}

\section{Isolation and sequencing of $\mathrm{ABH} 1$}

Extraction of a hot-SDS-insoluble residue of $A$. bisporus fruiting bodies with TFA solubilized proteins which upon PAGE showed three main bands, running at 16, 24 and $33 \mathrm{kDa}$ (Fig. 1, lane 1). By $\mathrm{N}$-terminal amino acid sequencing of the $16 \mathrm{kDa}$ band, the following sequence could be deduced: GKPKASSQCDVGEIHCCDTQQTPDHT. The underlined part was used for primer construction. The sequence $\mathrm{C}-\left(\mathrm{X}_{\mathrm{aa}}\right)_{6}$-C-C suggested the presence of a typical hydrophobin.

An antibody raised against the $16 \mathrm{kDa}$ protein reacted with all three bands (Fig. 1, lane 3). Moreover the three bands were found again after re-running the $16 \mathrm{kDa}$ protein (Fig. 1, lane 4). Apparently, the proteins running at 24 and $33 \mathrm{kDa}$ represent multimers or different conformational states of the $16 \mathrm{kDa}$ protein. Oxidation with performic acid produced a shift of the bands to a higher position on the gel (Fig. 1, lanes 1 and 2), as has been observed for other hydrophobins (de Vries $e t$ al., 1993). Staining for carbohydrate was negative, indicating

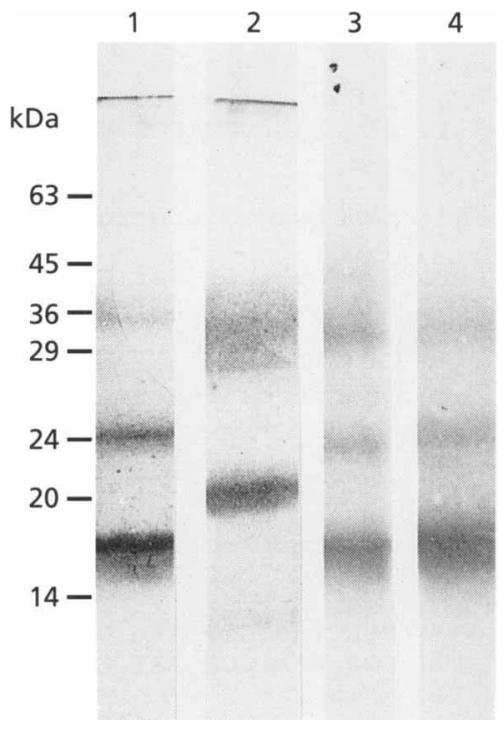

Fig. 1. SDS-PAGE of the SDS-insoluble protein fraction of $A$. bisporus fruiting bodies. Lanes 1 and 2, stained with silver; lanes 3 and 4 , immuno-staining with anti-ABH1. Lane 1, TFA treated; lane 2, performic acid treated; lane 3, TFA treated; lane 4, 16 kDa band extracted from gel and run again.

the absence of extensive glycosylation as present in the SC3 hydrophobin of S. commune (Ásgeirsdóttir, 1994).

\section{Gene isolation and sequencing}

In order to isolate the cDNA encoding the $16 \mathrm{kDa}$ protein, a degenerate primer was synthesized based on the amino acid residues $10-17$ of the $\mathrm{N}$-terminal sequence (see above). This sequence was chosen because it allowed the construction of a primer with minimal degeneracy. The primer, 5'-CTCTAGAGCTCGA(T/C)GT(T/C/A/G)GG(T/C/A/G)GA(A/G)AT(T/C)CA(T/C)TG(T/C)TG-3', contained an additional $S a c$ I restriction site (underlined). During PCR with a reverse primer containing oligo-d $\mathrm{T}_{26}$ and an $\mathrm{XboI}$ site in addition, elongation was expected to start downstream of the cysteine cluster.

RT-PCR with a total RNA extract of $A$. bisporus pinheads produced a single band approximately $480 \mathrm{bp}$ in length. A 300 bp SacI-XhoI fragment could be isolated containing an ORF for a protein with a second cysteine cluster inframe with the amino acid sequence encoded by the forward primer. The deduced amino acid sequence of this cDNA identified a class I hydrophobin, referred to as ABH1 (Fig. 2). The RT-PCR fragment was used to screen a phage library in order to isolate the gene sequence. A $4 \cdot 1 \mathrm{kbp} H i n d I I I$ fragment was found to contain the $A B H 1$ gene, and a putative second hydrophobin gene $(A B H 2)$ in addition (Figs 2 and 3). To identify the position of the first intron in $A B H 1$, a complete cDNA clone was isolated by performing an RT-PCR using a primer which annealed at the deduced ATG start codon.

$A B H 2$ shows an overall identity of $78 \%$ with $A B H 1$ ( $80 \%$ if only exons are compared). Both genes contain 
АВH 1

Met Ile Ser Arg Val Leu Val Ala Ala Leu Val Ala Leu Pro Ala Leu Val Thr

ATG ATC TCT CGC GTC CTT GTC GCT GCT CTC GTC GCT CTC CCC GCT CTT GTT ACT gtgagtt

Ala Thr Pro Ala Pro Gly Lys

gat tgcatgcgcc tcgttggetg aaaatctca ctctcttttg cag GCA ACT CCT GCT CCC GGA AAG Pro Lys Ala Ser ${ }^{30}$ Ser Gln Cys Asp Val Gly Glu Ile His Cys $\stackrel{40}{C}$

CCT AAA GCC AGC AGT CAG TGC GAC GTC GGT GAA ATC CAT TGC T gtaagtatct cccatgacac

ys Asp Thr Gln Gln Thr Pro Asp His Thr cggegcactc catatcctca gegactttct ttttag GC GAC ACT CAG CAG ACT CCC GAC CAC ACC so Ser Ala Ala Ala Ser Gly Leu Leu Gly Val Pro Ile Asn Leu Gly Ala Phe Leu Gly Phe 257 AGC GCC GCC GCG TCT GGT TTG CTT GGT GTT CCC ATC AAC CTT GGT GCT TTC CTC GGT TTC Asp Cys Thr Pro Ile ser Val Leu Gly Val $\stackrel{80}{70}$ G Gly Asn Asn Cys Ala Ala Gln Pro Val GAC TGT ACC CCC ATT TCC GTC CTT GGC GTC GGT GGC AAC AAC TGT GCT GCT CAG CCT GTC Cys Cys Thr Gly Asn Gin Phe

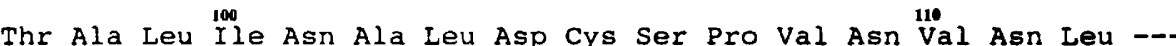
ctc tcttcag ACC GCA TTG ATT AAC GCT CTT GAC TGC TCT CCT GTC AAT GTC AAC CTC TAG

\section{ABH2}

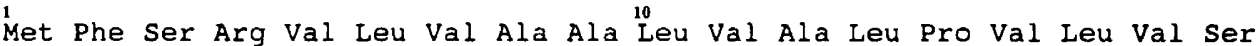

1 ATG TTC TCT CGC GTC CTC GTC GCA GCT CTT GTT GCT CTC CCC GTT CTC GTT TCC gtgagtt

gac taccctcatt gactgaatc atttactcac cctctttcgt ag GCA AGT CCC ACT CCT GGC GGA Tyr Pro Asp Ser Thr Thr Val Val Ser Gln Cys Asn Val Gly $\stackrel{40}{0}^{0}$ u Leu His Cys C

gtctat tccatgacat ctatgtactc catatcctca gtgacttctt ccag GC AAC ACT CAG CAA ACC

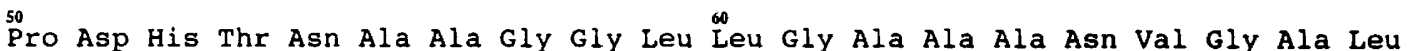
CCC GAC CAC ACC AAC GCC GCC GGC GGT CTG CTT GGT GCT GCC GCC AAC GTC GGC GCC CTC Leu Gly Phe Asp Cys Thr Pro Ile ser Val Ile Gly Ile Gly Gly Asn Asn Cys Ala Ala CTC GGT TTC GAC TGT ACC CCC ATT TCC GTC ATT GGC ATC GGT GGC AAC AAC TGT GCT GCT Gin Pro Val Cys Cys Glu Ala Asn Glu Phe

374 CAG CCC GTC TGC TGT GAA GCC AAC GAA TTC gtagttaga gettctggtc tttgacttaa aatcta

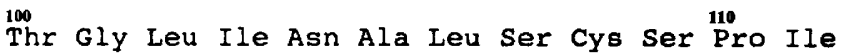
466 atact attctctctc tetctccect cag ACC GGG TTG ATT AAT GCT CTT AGC TGC TCT CCC ATC Asn Val Asn Leu --5o4 AAT GTC AAC CTT TAG

Fig. 2. Nucleotide sequences and deduced amino acid sequences of $A B H 1$ and $A B H 2$ of $A$. bisporus. The coding nucleotides are in upper-case letters and introns in lower-case letters. Both nucleotide and amino acid sequences are numbered with reference to the translation start point. Underlined are positions that differ in an allele isolated from the brown variant C9: Asp $\rightarrow$ Asn, Ala $\rightarrow$ Gly.

three short introns at the same positions of about 50 base pairs, with splice sites and internal splice signals which conform to the consensus sequences for introns of filamentous fungi (Gurr et al., 1987). In both genes the middle intron splits the third cysteine codon (Fig. 2). The two hydrophobin genes code for proteins with lengths of $112(\mathrm{ABH} 1)$ and 115 (ABH2) amino acids. After alignment the deduced amino acid sequences show $75 \%$ identity and
$7 \%$ similarity in addition. The homology with hydrophobins from other species is much less. For instance the homology between $\mathrm{ABH} 1, \mathrm{ABH} 2$ and the $S$. commune hydrophobins SC3 and SC4 is $34 \%$ identity and $42.5 \%$ and $36 \%$ similarity, respectively, with more homology found in the C-terminal part (Fig. 4). Remarkable is the homology of a box of six amino acids in the N-terminal part of ABH2 and SC3 (boxed amino acids in Fig. 4). 


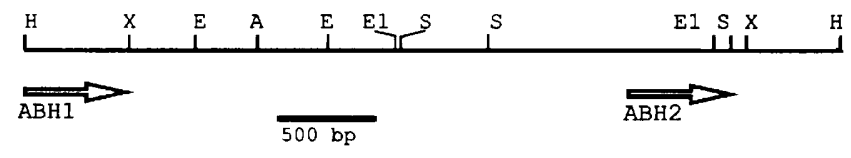

Fig. 3. Genomic organization of a $4 \cdot 1 \mathrm{kbp}$ Hindll fragment of A. bisporus DNA containing $A B H 1$ and $A B H 2$. Restriction analysis, sequencing and hybridization with the $A B H 1$ CDNA showed the location of the two genes and the direction of transcription (arrows). Restriction sites: H, HindIII; X, Xhol; E, EcoRV; A, Apal; E1, EcoRI; S, Sall.

Another $A B H 1$ allele was found in the brown variant $\mathrm{C}$, which showed amino acid substitutions at two positions (Fig. 2).

The hydropathy plots of both deduced proteins are similar to those of other known class I hydrophobins (Fig. 5; see Wessels, 1994). ABH1 and ABH2 apparently contain hydrophobic signal sequences for secretion. Processing of ABH1 takes place between a Pro and a Gly, as found in SC3 and SC4 (Schuren \& Wessels, 1990; Wessels et al., 1991); the same possibly also occurs in ABH2, but since the mature protein was not isolated this remains conjectural.

As in most genes of filamentous fungi (Gurr et al., 1987), codon usage in $A B H 1$ and $A B H 2$ is strongly biased. At the third codon position a $C$ or a $T$ is preferred where possible and less than $10 \%$ of the codons end with $\mathrm{G}$ or A. This resembles the codon usage in other $A$. bisporus genes (van der Vlugt et al., 1993).

\section{Expression of hydrophobins}

RT-PCR of RNA using the $A B H 1$ primer described above and oligo-dT as reverse primer showed a band of approximately $480 \mathrm{bp}$ in the case of fruiting-body RNA
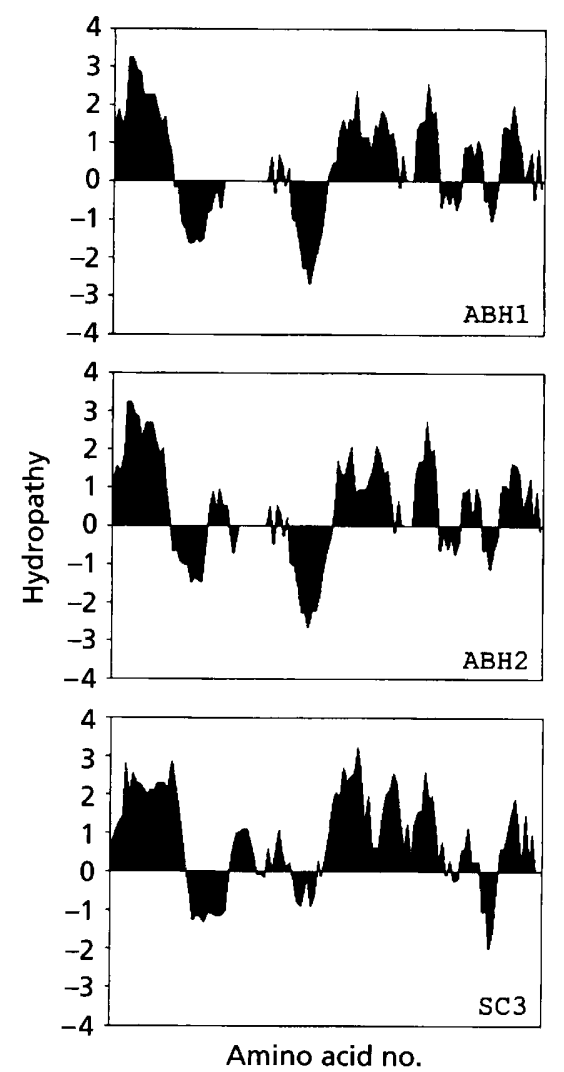

Fig. 5. Hydropathy plot of $A B H 1, A B H 2$ and $S C 3$. The sequences have been aligned at the first, fourth and fifth cysteine residue. The hydropathy values were calculated following Kyte \& Doolittle (1982), using a window size of six amino acids.

only (Fig. 6, lanes 2 and 3). Using a primer specific for a mRNA from the substrate mycelium (see Discussion), a specific fragment of $440 \mathrm{bp}$ was amplified from the

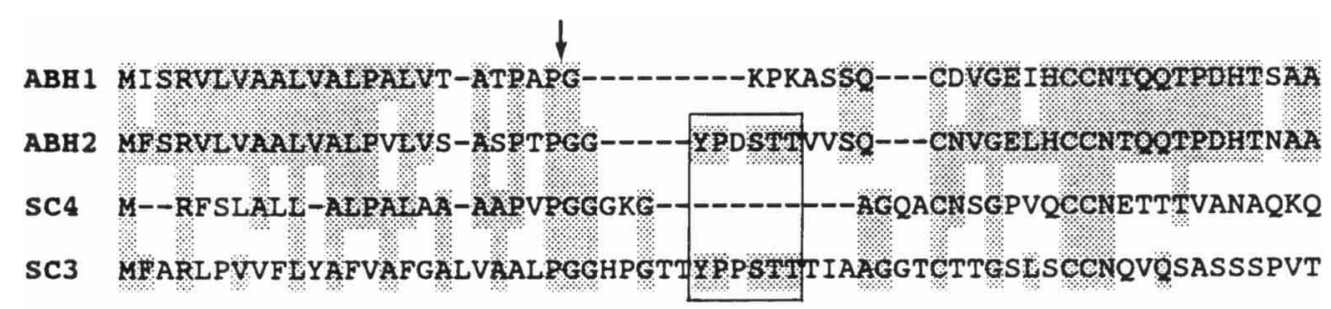

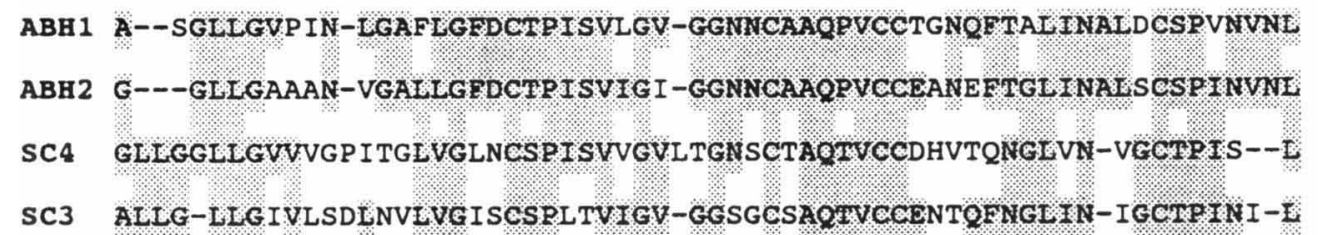

Fig. 4. Alignment of the $A B H 1$ and $A B H 2$ amino acid sequences with those of $S C 3$ and $S C 4$ from $S$. commune according to the CLUSTAL program of the PC/Gene program package, version 6.60 (Higgins \& Sharp, 1988). Shaded amino acids indicate identities. The processing sites in $\mathrm{ABH} 1, \mathrm{SC} 3$ and $\mathrm{SC} 4$ are indicated by an arrow. A homologous box of six amino acids in the $\mathrm{N}$-terminal part of $\mathrm{ABH} 2$ and $\mathrm{SC} 3$ is indicated. 


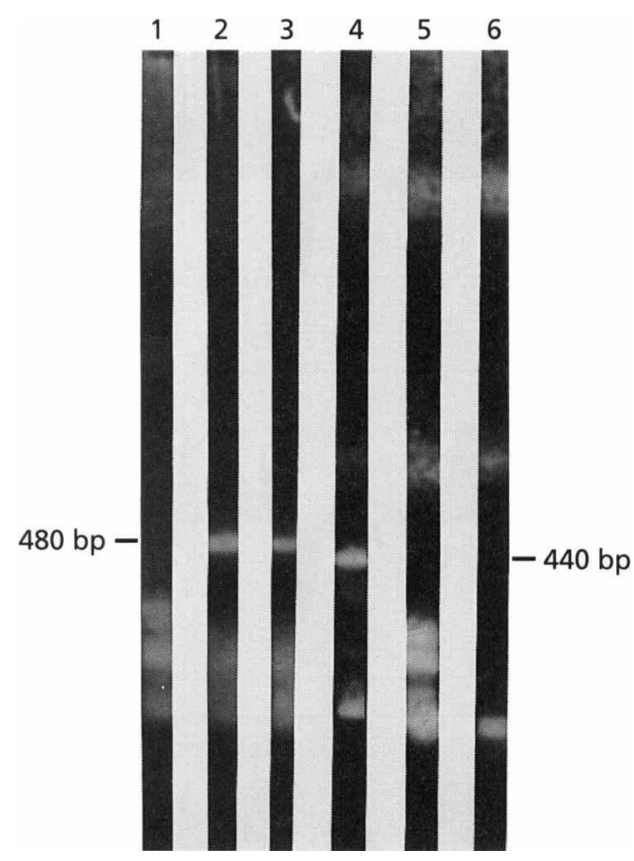

Fig. 6. Agarose gel electrophoresis of RT-PCR products using an ABH1-specific primer (lanes 1-3) and a primer for an mRNA specific for the substrate mycelium (lanes 4-6). Lanes 1 and 4, substrate mycelium CDNA; lanes 2 and 5, fruiting-body CDNA (pinhead stage); lanes 3 and 6 , fruiting-body CDNA (button stage).

mycelial RNA only (lanes 4). This shows the integrity of the RNAs from both sources.

In agreement with the PCR result, an $A B H 1$ cDNA only hybridized to fruiting-body RNA on Northern blots and not with mycelial RNA (results not shown). In addition, no $\mathrm{ABH} 1$ could be immunologically detected among proteins secreted by the substrate mycelium (results not shown). Together, these results strongly suggest that $\mathrm{ABH} 1$ is only expressed in fruiting bodies of $A$. bisporus. Since only one hydrophobin could be detected in the hotSDS-insoluble protein fraction ( $\mathrm{N}$-terminal sequencing gave no indication of the presence of another hydrophobin), the $A B H 2$ gene, if coding for a class I hydrophobin, is apparently not, or is very poorly, expressed in fruiting bodies.

\section{Localization of ABH1}

Immuno-localization showed that $\mathrm{ABH} 1$ is present throughout the fruiting body (Fig. 7). Only the gills were completely unreactive to anti-ABH1. High reactivity was seen in the outer region of pileus and stipe, in the veil and in the core of the stipe. In the inner tissue of pileus and stipe an irregular pattern of weak staining was observed (Fig. 7).

To obtain quantitative information on $\mathrm{ABH} 1$ content in different fruiting body parts, a large fruiting body ( $180 \mathrm{~g}$ wet wt) was dissected into various fractions (Table 1). Hot-SDS-extracted residues were prepared as described in
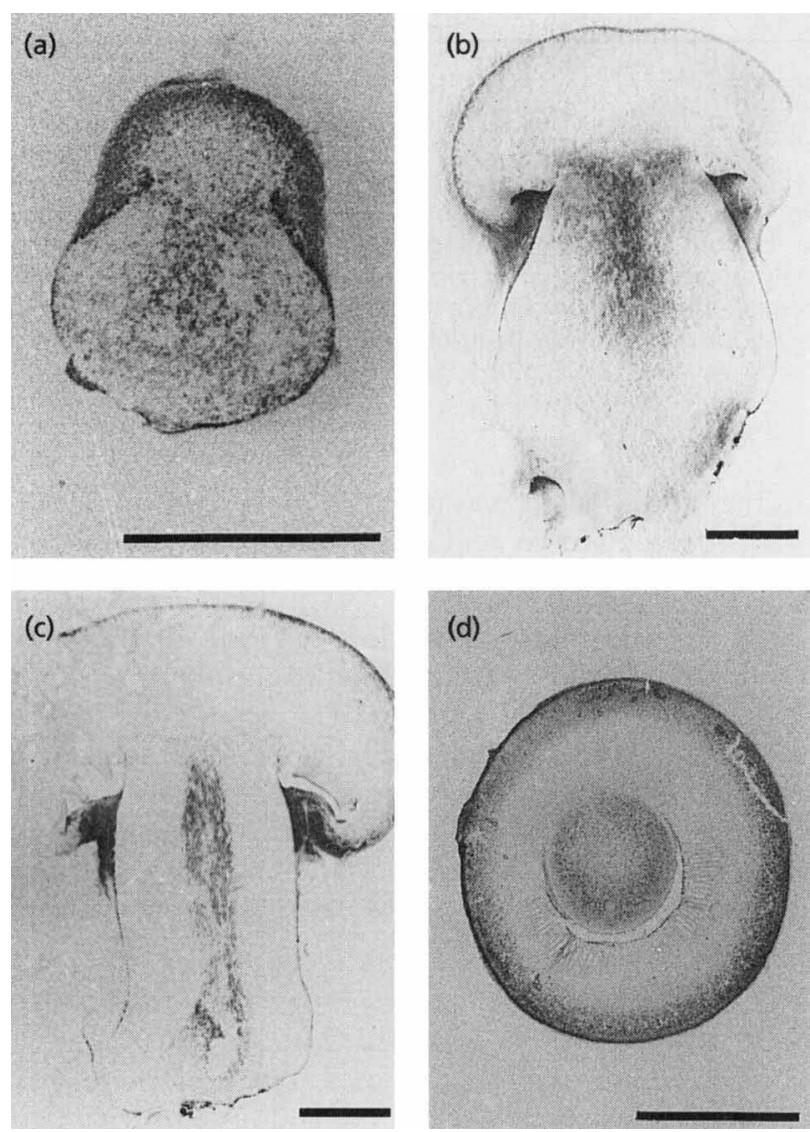

Fig. 7. Immuno-localization of $A B H 1$ in the fruiting body of $A$. bisporus. (a) One-day-old fruiting body (pinhead). (b) Threeday-old fruiting body (button). (c) Four-day-old fruiting body. Note that the roof of the hymenial cavity containing the gills appears free of $\mathrm{ABH} 1$; the bottom of the cavity represented by the veil is darkly stained. (d) Transverse section taken through the cap gill tissue of a four-day-old fruiting body. Bars, $0.5 \mathrm{~cm}$.

Methods and equal amounts (by dry weight) of the residues were extracted with TFA. TFA extracts were run on SDS-PAGE and the relative amounts of ABH1 estimated by comparing the intensity of the $16 \mathrm{kDa}$ band after staining with Coomassie Blue. The results (Table 1) confirm the qualitative results of immuno-localization. ABH1 turned out to be present in all fractions except the gills; $75 \%$ of $\mathrm{ABH} 1$ was found in the cap outer tissue, constituting only $10 \%$ of the fresh weight of the fruiting body. The inability to detect $\mathrm{ABH} 1$ in gill tissue containing immature spores indicates, but does not prove, the absence of $\mathrm{ABH} 1$ in these structures.

\section{Interfacial assembly of ABH1}

ABH1 was isolated and purified as described in Methods. Discs of Teflon were immersed in an aqueous solution of ABH1 (approx. $20 \mu \mathrm{g} \mathrm{ml}^{-1}$ ) for $16 \mathrm{~h}$. The Teflon discs were then washed with water, dried and contact angles of $1 \mu \mathrm{l}$ water droplets were measured. Contact angle values dropped from $110^{\circ}$ for uncoated to $63 \pm 8^{\circ}$ for coated Teflon, with lowest values of $51^{\circ}$. ABH1 antiserum 
Table 1. Estimation of relative abundance of $A B H 1$ in TFA extracts of hot-SDS-insoluble residues derived from different parts of a large fruiting body

\begin{tabular}{|c|c|c|c|c|}
\hline \multirow[t]{3}{*}{ Part of fruiting body } & \multirow{3}{*}{$\begin{array}{c}\text { Wet wt } \\
\text { (g) }\end{array}$} & \multicolumn{3}{|c|}{ SDS-insoluble residue } \\
\hline & & \multirow[t]{2}{*}{$\begin{array}{c}\text { Dry wt } \\
\text { (mg) }\end{array}$} & \multicolumn{2}{|c|}{$\begin{array}{c}\text { Relative amount } \\
\text { ofABH1 } \\
\text { (16 kDa protein) }\end{array}$} \\
\hline & & & per mg & $\begin{array}{l}\% \text { of } \\
\text { total }\end{array}$ \\
\hline Outer cap layer & $17 \cdot 9$ & 628 & $1 \cdot 00$ & 75 \\
\hline Inner cap & $106 \cdot 8$ & 951 & 0.05 & 6 \\
\hline Gills & $21 \cdot 1$ & 288 & $0 \cdot 00$ & 0 \\
\hline Outer stipe layer & $3 \cdot 2$ & 92 & $0 \cdot 25$ & 3 \\
\hline Inner stipe & $30 \cdot 9$ & 690 & $0 \cdot 20$ & 16 \\
\hline Total & $179 \cdot 1$ & 2649 & $0 \cdot 32$ & 100 \\
\hline
\end{tabular}

* Relative amounts of ABH1 were estimated by comparing intensities of the $16 \mathrm{kDa}$ protein band after SDS-PAGE and Coomassie Blue staining of serial dilutions of TFA extracts from equal amounts (dry weight) of SDS-insoluble residues. Values are the means of two determinations, which deviated from each other by less than $10 \%$.

reacted with $\mathrm{ABH} 1$ assembled on Teflon, showing antigenic epitopes at the hydrophilic side of the coating. After extraction of the ABH1-coated discs with 1\% SDS at $100{ }^{\circ} \mathrm{C}$ for $10 \mathrm{~min}$ no decrease was observed in reaction with the antibody. However the contact angle values increased to $84 \pm 7^{\circ}$, with lowest values of $72^{\circ}$. For measuring contact angles at the hydrophobic side of an $\mathrm{ABH} 1$ film, paper strips were coated with $\mathrm{ABH} 1$ as described in Methods. The paper became hydrophobic in an area just beneath the evaporating front, where water contact angles of $113 \pm 4^{\circ}$ were measured after extraction with hot SDS. The outer surface of the fruiting body cap displayed water contact angles of up to $130^{\circ}$. After extraction of tissue strips with chloroform/methanol $(2: 1, \mathrm{v} / \mathrm{v})$ at $65^{\circ} \mathrm{C}$ (five times, $10 \mathrm{~min}$ ), surface water contact angles were unchanged. The high hydrophobicity of the fruiting body surface would thus appear to be largely due to the $\mathrm{ABH} 1$ hydrophobin.

To investigate the ultrastructure of assembled ABH1, a solution of this protein was allowed to dry on Formvarcoated grids and shadowed. The surface, representing the hydrophobic face, showed a mosaic pattern of parallel rodlets $10 \mathrm{~nm}$ wide (Fig. 8a). To examine the presence of rodlets in vivo, fragments of outer and inner cap tissue were freeze-fractured and surface replicas viewed in the electron microscope. Patches with rodlets were generally observed in both cases (Fig. 8b, c) but it was not clear whether the rodlets were completely covering hyphal surfaces or only surfaces exposed to air. Replicas made directly from the surface of the outer cap tissue (without breaking) also exhibited rodlets (Fig. 8d). This proves that the $\mathrm{ABH} 1$ rodlet layer is the outermost stratum of the fruiting body pileus.

\section{DISCUSSION}

Genes encoding class I hydrophobins have mostly been identified by sequencing $\mathrm{cDNAs}$ corresponding to mRNAs that are highly expressed at certain stages of fungal development (Wessels, 1994). Only in the case of hydrophobin genes responsible for rodlet layers on conidia within related Aspergillus species has sequence similarity been used to isolate the homologous genes (Parta et al., 1994; Thau et al., 1994). On the other hand, genes for the class II hydrophobins cerato-ulmin and cryparin were cloned on the basis of knowledge about amino acid sequences (Bowden et al., 1993; Zhang et al., 1994). Since assemblages formed by class I hydrophobins are insoluble in hot SDS, in contrast to those formed by class II hydrophobins (Wessels, 1994), we decided to clone class I hydrophobin genes of $A$. bisporus starting with the $\mathrm{N}$-terminal sequence of any protein resisting hotSDS extraction.

A hot-SDS-insoluble complex that could be dissociated with TFA into a single $16 \mathrm{kDa}$ protein was earlier found in the cell walls of vegetatively-growing $A$. bisporus by de Vries $e t$ al. (1993). In the present paper we describe the isolation and purification of a similarly-sized protein (ABH1) with all the properties of a class I hydrophobin from a hot-SDS-insoluble residue from fruiting bodies of this species. The cDNA sequence isolated on the basis of RT-PCR reveals the expected homology to class I hydrophobin genes cloned from Schizopbyllum commune and other fungi, particularly with respect to spacings of cysteine residues and hydropathy plots. In addition, sequencing of the genomic fragment that harbours the $A B H 1$ gene revealed a highly homologous second hydrophobin gene $(A B H 2) 2.58 \mathrm{kbp}$ downstream of ABH1.

No transcript for the $A B H 2$ gene was found but the $A B H 1$ mRNA was abundant in the fruiting bodies. Whether $A B H 2$ is an inactive gene or is transcribed into a low-abundance mRNA requires further investigation. Significantly, the $A B H 1$ transcript appeared to be absent from the substrate mycelium, indicating that $A B H 1$ is specifically expressed in fruiting bodies. However, this substrate mycelium does secrete another class I hydrophobin into the culture medium (L. G. Lugones \& J. G. $\mathrm{H}$. Wessels, unpublished data). The gene $(A B H 3)$ for this hydrophobin is currently being cloned and a degenerate primer based on its $\mathrm{N}$-terminal amino acid sequence detects an mRNA that is present in the substrate mycelium but not in the fruiting bodies (Fig. 6).

We have demonstrated that $\mathrm{ABH} 1$ assembles in vitro into an SDS-insoluble amphipathic protein film when confronted with hydrophobic-hydrophilic interfaces, as earlier shown for the SC3 hydrophobin of $S$. commune (Wösten et al., 1993, 1994a, b). In fact, this is the second class I hydrophobin for which this remarkable property has now been reported. In addition, we have shown that ABH1, like the SC3 hydrophobin of $S$. commune (unpublished), can assemble at the surface of cellulose fibres, coating them with an SDS-insoluble layer that confers non-wettability (water contact angles $110^{\circ}$ ). We thus 

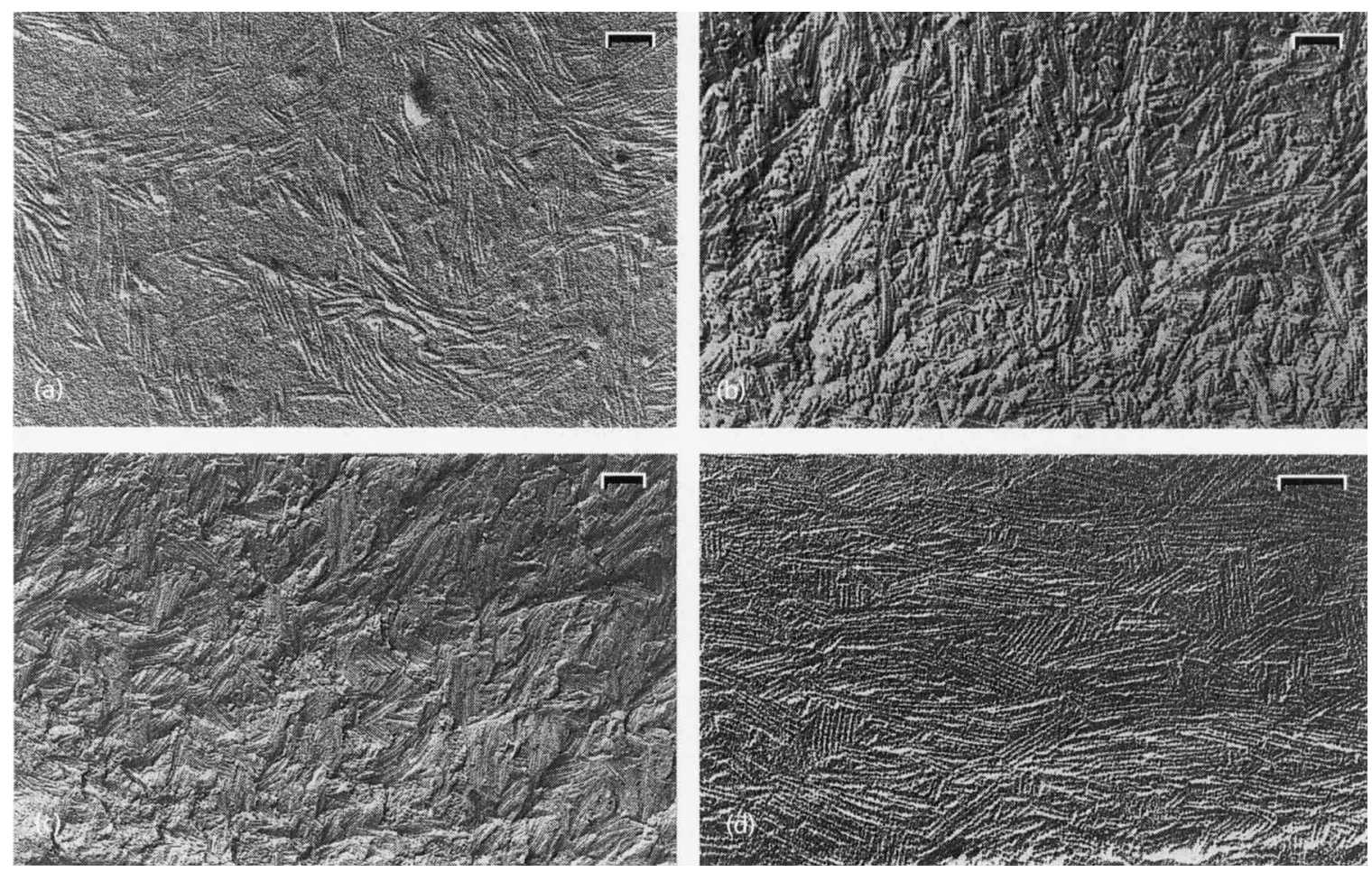

Fig. 8. Ultrastructure of assembled $\mathrm{ABH} 1$. (a) In vitro-assembled $\mathrm{ABH} 1$ after shadowing. (b) Replica of the cap plectenchyma after freeze-fracturing. (c) Replica of the surface of the cap after freeze-fracturing. (d) Replica of the surface of the cap. Bars, $100 \mathrm{~nm}$.

propose that $\mathrm{ABH} 1$ secreted by fruiting-body hyphae of A. bisporus self-assembles at the wall-air interface, coating these hyphae with an insoluble ABH1 film that exposes its rodlet-decorated hydrophobic side towards the air. This would be similar to the mechanism earlier proposed for formation of the hydrophobic rodlet layer on aerial hyphae of S. commune (Wösten et al., 1994b). Indeed, immuno-histochemistry with an $\mathrm{ABH} 1$ antiserum and electrophoretic detection of $\mathrm{ABH} 1$ in dissected fruitingbody parts showed that $\mathrm{ABH} 1$ is most abundant at the surface of the fruiting body, while replicas of the cap surface suggest that the outer surface of the fruiting body is completely covered by a rodlet layer made of ABH1. This layer may be solely responsible for the nonwettability of the surface of the fruiting body. Its main function may be prevention of inflow of water from the outside and protection of the fruiting body against bacterial and fungal parasites. Whether the extremely thin hydrophobin layer (approx. $10 \mathrm{~nm}$ ) prevents water loss from the fruiting body is doubtful. Because the hydrophobic outer stratum of the fruiting body should not impede metabolic gas exchange too much, we surmise that the hydrophobin layer is also freely permeable to water vapour.

It has been shown that the SC3 hydrophobin probably fulfils a similar function as $\mathrm{ABH} 1$ at the surface of fruiting bodies of $S$. commune while the SC3 hydrophobin is excluded from the inner tissue of fruiting bodies where another hydrophobin (SC4) is prevalent (Mulder \& Wessels, 1986; Ásgeirsdóttir et al., 1995). The SC4 hydrophobin assemblages seem to line walls of air channels that traverse the fruiting-body plectenchyma, probably conferring hydrophobicity to the channel walls and preventing water penetration (Wessels et al., 1995). Localization of $\mathrm{ABH} 1$ shows that this hydrophobin is not confined to the surface but occurs throughout the fruiting body of $A$. bisporus. Within the fruiting body it is most abundant in the centre of the stipe, where hyphae are most loosely packed (Craig et al., 1979), suggesting the presence of $\mathrm{ABH} 1$ where air is present. Freeze-fracture replicas show that rodlets occur inside the fruiting bodies (Fig. $8 b)$, probably where air spaces occur within the plectenchyma. Apart from its role at the surface, ABH1 thus may fulfil a function within the plectencyma of $A$. bisporus fruiting bodies similar to that played by SC4 in $S$. commune.

\section{ACKNOWLEDGEMENTS}

We are indebted to $\mathrm{Mr} \mathrm{J}$. Zagers for doing the electron microscopy. We also thank J. H. Sietsma, F. H. J. Schuren and H. A. B. Wösten for stimulating discussions and advice.

\section{REFERENCES}

Ásgeirsdóttir, S. A. (1994). Proteins involved in emergent growth of Schizophyllum commune. PhD Thesis, University of Groningen.

Ásgeirsdóttir, S. A., van Wetter, M. A. \& Wessels, J. G. H. (1995). Differential expression of genes under control of the mating-type genes in the secondary mycelium of Schizopbyllum commune. Microbiology 141, 1281-1288. 
Bell-Pedersen, D., Dunlap, J. C. \& Loros, J. J. (1992). The Neurospora circadian clock-controlled gene, $c c q-2$, is allelic to eas and encodes a fungal hydrophobin required for formation of the conidial rodlet layer. Genes Dev 6, 2382-2394.

Bowden, C. G., Hintz, W. E., Jeng, R., Hubbes, M. \& Horgen, P. A. (1994). Isolation and characterization of the cerato-ulmin toxin gene of the Dutch elm disease pathogen, Ophiostoma ulmi. Curr Genet 25, 323-329.

Craig, G. D., Newsam, R. J., Gull, K. \& Wood, D. A. (1979). An ultrastructural and autoradiographic study of stipe elongation in Agaricus bisporus. Protoplasma 98, 15-29.

Dons, J. J. M., de Vries, O. M. H. \& Wessels, J. G. H. (1979). Characterization of the genome of the basidiomycete Schizopbyllum commune. Biochim Biophys Acta 563, 100-112.

Gurr, S. J., Unkles, S. E. \& Kinghorn, J. R. (1987). The structure and organization of nuclear genes in filamentous fungi. In Gene Structure in Eukaryotic Microbes, pp. 93-139. Edited by J. R. Kinghorn. Oxford: IRL Press.

Harmsen, C. M., Schuren, H. J., Moukha, S. M., van Zuilen, C. M., Punt, J.P. \& Wessels, J. G. H. (1992). Sequence analysis of the glyceraldehyde-3-phosphate dehydrogenase genes from the basidiomycetes Schizophyllum commune, Phanerochaete chrysosporium and Agaricus bisporus. Curr Genet 22, 447-454.

Higgins, D. G. \& Sharp, P. M. (1988). Clustal, a package for performing multiple sequence alignments in a microcomputer. Gene 73, 237-244.

Kyte, J. \& Doolittle, R. F. (1982). A simple method for displaying the hydrophobic character of a protein. J Mol Biol 157, 105-132.

Laemmli, U. K. (1970). Cleavage of structural proteins during the assembly of the head of bacteriophage T4. Nature 227, 680-685.

Lauter, F. R., Russo, V. E. A. \& Yanofsky, C. (1992). Developmental and light regulation of eas, the structural gene for the rodlet protein of Neurospora. Genes Dev 6, 2373-2381.

van der Mei, H. C., Rosenberg, M. \& Busscher, H. J. (1991). Assessment of microbial cell surface hydrophobicity. In Micrabial Cell Surface Analysis, pp. 261-287. Edited by N. Mozes, P. S. Handley, H. J. Busscher \& P. G. Rouxhet. New York: VCH.

Merril, C. R., Goldman, D., Sedman, S. A. \& Ebert, M. H. (1981). Ultrasensitive stain for proteins in polyacrylamide gels shows regional variation in cerebrospinal fluid proteins. Science 211, $1437-1438$

Mulder, G. H. \& Wessels, J. G. H. (1986). Molecular cloning of RNAs differentially expressed in monokaryons and dikaryons of Scbizopbyllum commune. Exp Mycol 10, 214-227.

Neuhof, V., Arold, N., Taube, D. \& Erhardt, W. (1988). Improved staining of proteins in polyacrylamide gels including isoelectric focusing gels with clear background at nanograms sensitivity using Coomassie Brilliant Blue G-250 and R-250. Electrophoresis 9, 255-262.

Parta, M., Chang, Y., Rulong, S., Pinto-DaSilva, P. \& Kwon-Chung, K. J. (1994). HYP1, a hydrophobin gene from Aspergillus fumigatus, complements the rodletless phenotype in Aspergillus nidulans. Infect Immun 62, 4389-4395.

Richards, W. C. (1993). Cerato-ulmin, a unique wilt toxin of instrumental significance in the development of Dutch elm disease. In Dutch Elm Disease Research, Cellular and Molecular Approaches, pp. 89-151. Edited by M. B. Sticklen \& J. L. Sherald. New York: Springer Verlag.

Sanger, F., Nicklen, S. \& Coulson, A. R. (1977). DNA sequencing with chain terminating inhibitors. Proc Natl Acad Sci USA 74, 5463-5467.
Schuren, F. H. J. \& Wessels, J. G. H. (1990). Two genes specifically expressed in fruiting dikaryons of Schizophyllum commune, homologies with a gene not regulated by mating-type genes. Gene 90, 199-205.

Schuren, F. H. J., Harmsen, M. C. \& Wessels, J. G. H. (1993). A homologous gene-reporter system for the basidiomycete Schizophyllum commune based on internally deleted homologous genes. Mol Gen Genet 238, 91-96.

Sietsma, J. H., Rast, D. \& Wessels, J. G. H. (1977). The effect of carbon dioxide on fruiting and on the degradation of a cell-wall glucan in Schizopbyllum commune. J Gen Microbiol 102, 385-389.

Stringer, M. A., Dean, R. A., Sewall, T. C. \& Timberlake, W. E. (1991). Rodletless, a new Aspergillus developmental mutant induced by directed gene inactivation. Genes Dev 5, 1161-1171.

Thau, N., Monod, M., Crestani, B., Rolland, C., Tronchin, G., Latgé, J. P. \& Paris, S. (1994). Rodletless mutants of Aspergillus fumigatus. Infect Immun 62, 4380-4388.

van der Vlugt, R. A. A., Schaap, P. J., Müller, Y., Thurston, C. F., Sonnenberg, A. S. M., Visser, J. \& van Griensven, L. J. L. D. (1993). A codon usage table for Agaricus bisporus. Cultivated Musbroom Res Newsl 1, 50-52.

de Vries, O. M. H., Fekkes, M. P., Wösten, H. A. B. \& Wessels, J. G. H. (1993). Insoluble hydrophobin complexes in the walls of Schizopbyllum commune and other filamentous fungi. Arch Microbiol 159, 330-335.

Wessels, J. G. H. (1994). Developmental regulation of fungal cell wall formation. Annu Rev Pbytopatbol 32, 413-437.

Wessels J. G. H., Mulder G. H. \& Springer, J. (1987). Expression of dikaryon-specific and non-specific $\mathrm{mRNAs}$ of Scbizophyllum commune in relation to environmental conditions and fruiting. J Gen Microbiol $133,2557-2561$

Wessels, J. G. H., de Vries, O. M. H., Ásgeirsdóttir, S. A. \& Schuren, F. H. J. (1991). Hydrophobin genes involved in formation of aerial hyphae and fruit bodies in Schizopbyllum commune. Plant Cell 3, 793-799.

Wessels, J. G. H., Ásgeirsdóttir, S. A., Birkenkamp, K. U., de Vries, O. M. H., Lugones, L. G., Schuren, F. H. J., Schuurs, T. A., van Wetter, M. A. \& Wösten, H. A. B. (1995). Genetic regulation of emergent growth in Schizopbyllum commune. Can J Bot $\mathbf{7 3}$ (Suppl. 1), S273-S281.

Wösten, H. A. B., de Vries, O. M. H. \& Wessels, J. G. H. (1993). Interfacial self-assembly of a fungal hydrophobin into a hydrophobic rodlet layer. Plant Cell 5, 1567-1574.

Wösten, H. A. B., Schuren, F. H. J. \& Wessels, J. G. H. (1994a). Interfacial self-assembly of a fungal hydrophobin into an amphipathic membrane mediates fungal attachment to hydrophobic surfaces. EMBO J 13, 5848-5854.

Wösten, H. A. B., Ásgeirsdóttir, S. A., Krook, J. H., Drenth, J. H. H. \& Wessels, J. G. H. (1994b). The fungal hydrophobin SC3p selfassembles at the surface of aerial hyphae as a protein membrane constituting the hydrophobic rodlet layer. Eur J Cell Biol 63, 122-129.

Zhang, L., Villalon, D., Sun, Y., Kazmierczac, P. \& van Alfen, N. K. (1994). Virus-associated down-regulation of the gene encoding cryparin, an abundant cell-surface protein from the chestnut blight fungus Cryphonectria parasitica. Gene 139, 59-64.

Received 8 November 1995; revised 19 January 1996; accepted 26 January 1996. 